\title{
Development of clovers that are tolerant to clover root weevil
}

\author{
J. R. CRUSH ${ }^{1}$, B. M. COOPER ${ }^{2}$, D. R. WOODFIELD ${ }^{3}$ and P. J. GERARD ${ }^{1}$ \\ ${ }^{1}$ AgResearch, Ruakura Research Centre, PB 3123, Hamilton \\ ${ }^{2}$ AgResearch, P.O. Box 23, Kerikeri \\ ${ }^{3}$ AgResearch, Grasslands Research Centre, PB 11008, Palmerston North \\ jim.crush@agresearch.co.nz
}

\begin{abstract}
Clover root w eevil (CRW) has become a major pest of white clover in pastures in much of the North Island. In contemporary, intensively stocked pastures, high volumes of nitrogen $(\mathrm{N})$ cycling through the soil/plant/ animal system stimulate grass growth and reduce the clover content of pastures. Clover root weevil imposes further stresses on clovers. A range of white and red clover germplasm was evaluated for CRW tolerance from 2002-2005 on Waikato dairy and sheep/beef farms. Results confirmed the importance of good agronomic adaptation if clovers are to survive the additional stress of CRW. Two recently released white clover cultivars (Grasslands Kopu II and Tribute) were amongst the top performing lines under dairy farm grazing. Under sheep/ beef grazing, spreading type red clovers also performed well. A white clover breeding line selected for tolerance of plant-feeding nematodes was in the top group of clovers at both sites. Reducing stresses on clovers from other pasture pests will contribute to improved tolerance to CRW. A glasshouse experiment showed that CRW larval feeding can severely damage white clover nodules and reduce $\mathrm{N}$ fixation. The plants have considerable capacity to grow new nodules but this diverts energy away from other growth processes. Our conclusions are that welladapted, vigorous white clover cultivars are better able to cope with the additional stress imposed by the root weevil. Good pasture management and attention to fertiliser requirements can improve clover survival under root weevil herbivory. New generation red clovers show considerable potential for weevil infested areas. Coselection for tolerance/resistance to other major clover pests e.g. clover flea and root nematodes will improve plant performance under CRW stress.
\end{abstract}

Keywords: clover root weevil, nitrogen fixation, plant breeding, red clover, white clover

\section{Introduction}

The pasture pest CRW (Sitona le pidus) is now established over much of the North Island. Damage to white clover in dairy pastures has been sporadic, and sometimes severe. Waikato dairy far mers report that "clovers are not doing what they used to", and CRW often gets the blame. However trends in dairying over the last 10 years such as increased stocking rate with high rates of pasture utilisation are, in effect, driving pastures fur ther up Sear's
(1962) pasture development curve. The result of this transition is increasing volumes of nitrogen $(\mathrm{N})$ cycling through the soil/plant/ animal system, and inevitably a reduction in the clover content of pastures. Clovers cannot be expected to "do what they used to do" because contemporary dairy pastures are different ecologically. Within a region, and even within farms, there will be paddocks representing different stage of the pasture development curve. Superimposed on these grass/clover relationships, there are cyclical patterns of change in clover content over time (Steele 1982). Year-to-year change in clover content can be dramatic, usually reflecting variable summer rainfall. For example, farmlets under uniform dairy management near Hamilton had clover yields of 1.9 and 6.0 t dry matter (DM)/ha in 2000/2001 and 2001/2002 respectively (Crush unpublished data). Associated $\mathrm{N}$ fixation was 91 and $335 \mathrm{~kg} \mathrm{~N}$ ha/yr. This site had a substantial CRW population (Hardwick 2004) yet the clovers responded strongly to good summer growing conditions.

Modern clover cultivars bred for the high soil nutrient status typical of contemporary dairy pastures are more competitive with ryegrass under high $\mathrm{N}$ conditions and contribute more DM to the sward (Crush unpublished data). Such clovers would be expected to cope better with CRW, because they are under less stress due to their adaptation to contemporary pastures. On farms where weevil damage is severe, clover still thrives in low-stress situations e.g. along drains, raceways and in lawns (Eerens \& Hardwick 2003). Our current advice to farmers sowing white clover is to choose newer cultivars, welladapted for their production system, and manage the pasture for maximum clover vigour (Crush et al. 2004). Red clover is not readily eaten by CRW, and some modern red clovers show considerable promise under root weevil pressure (Cooper et al. 2003). The objective of the work reported here is to identify clover germplasm that is welladapted to cope with the additional stress imposed by CRW.

\section{Methods}

\section{Field trials}

Ten white clover cultivars, 40 breeding lines of white clover, two red clover cultivars, and 10 breeding lines of red clover were evaluated for vigour, from 2002-2005 under dairy, or sheep/beef grazing on two commercial 
Table 1 Soil test values for the trial sites on a dairy farm and a sheep/beef farm near Waerenga, North Waikato. $\mathrm{Ca}, \mathrm{K}, \mathrm{Mg}$, Na reported as MAF quick test values, Olsen $\mathrm{P}$ in $\mu \mathrm{g} / \mathrm{ml}, \mathrm{SO}_{4}-\mathrm{S}$ in $\mathrm{ppm}$.

\begin{tabular}{llllllccc}
\hline Farm & Soil & $\mathrm{pH}$ & $\mathrm{Ca}$ & $\mathrm{P}$ & $\mathrm{K}$ & $\mathrm{SO}_{4}-\mathrm{S}$ & $\mathrm{Mg}$ & $\mathrm{Na}$ \\
\hline Dairy & Alluvial & 5.7 & 8 & 41 & 8 & 7 & 25 & 5 \\
Sheep/beef & Hill & 5.5 & 7 & 11 & 5 & 10 & 23 & 7 \\
\hline
\end{tabular}

Table 2 Average vigour scores over three years, and numbers of clover lines in each category, for clovers evaluated under CRW pressure in Waikato dairy and sheep/beef pastures. At the dairy site the top ten clovers were all white clover and at the sheep/beef site there were six white clover and four red clovers.

\begin{tabular}{|c|c|c|c|c|c|}
\hline & \multirow[t]{2}{*}{ Category } & \multicolumn{2}{|c|}{ Cultivars } & \multicolumn{2}{|c|}{ _ Breeding lines } \\
\hline & & No. & Vigour score & No. & Vigour score \\
\hline \multirow[t]{3}{*}{ Dairy site } & Top 10 clovers & 2 & Kopu II 3.5 & 8 & $3.4-3.6$ \\
\hline & Other white clovers & 7 & 3.1 & 33 & 2.9 \\
\hline & Other red clovers & 2 & 2.8 & 10 & 2.8 \\
\hline \multirow[t]{3}{*}{ Sheep/beef site } & Top 10 clovers & 0 & & 4 & Red $3.2-3.3$ \\
\hline & Other whito clovarc & 10 & 29 & 34 & Wnite $3.2-3.5$ \\
\hline & Other red clovers & 2 & 2.8 & 6 & 2.3 \\
\hline
\end{tabular}

farms near Waereng a, North Waikato. The dairy farm had more fertile soil than the sheep/beef farm (Table 1) and it was always moister with higher growth rates. Resident clovers were sprayed out of areas of pasture with Dicamba and the test clovers planted in as young plants. Each clover type was represented by six, metrelong rows of 10 plants, in a randomised layout with $1 \mathrm{~m}$ spacing betw een rows. After establishment the sites were grazed with the rest of the paddock as part of normal farm management. The clovers were scored visually for vigour and pest damage symptoms before each grazing on the dairy farm. Scoring was less regular on the sheep/ beef farm due to periods of set stocking. Pasture pest monitoring confir med both sites had populations of CRW, clover flea, and plant feeding nematodes. Details are provided in Crush et al. (2004).

\section{Controlled experiment}

The effect of CRW larval feeding on growth and $\mathrm{N}$ fixation was tested on six white clover cultivars and six breeding lines of white clover in a glasshouse experiment. Stolon tip cuttings were taken from stock plants, rooted in sand trays, and inoculated with Rhizobium. The cuttings were supplied with a solution containing all necessary nutrients apart from $\mathrm{N}$, which was excluded to promote formation of nodules.

After 12 days, 20 rooted stolon tips of each of the 41 genotypes were weighed and transplanted to $10 \mathrm{~cm}$ diameter pots of sand. Application of the minus-N nutrient solution was continued throughout the experiment and day length was extended to $14 \mathrm{~h}$ with growth lamps. Average glasshouse day/night temperatures were 17 and $12^{\circ} \mathrm{C}$ respectively during the experiment.
Seven weeks after transplantation into the experimental pots, CRW eggs were added. Ten pots for each genotype received 50 eggs by weight, with the remaining 10 pots serving as controls.

Four w eeks after the addition of CRW eggs, the plants were trimmed and after two weeks of regrowth all plants were destructively harvested. The sand was washed away from the roots of the inoculated plants on a coarse sieve, and the larvae were trapped on a fine sieve. The larvae were then floated to the surface in a tray of magnesium sulphate solution, counted and preserved in ethanol. Roots and shoots were separated, blotted dry and dried at $70^{\circ} \mathrm{C}$ for $24 \mathrm{hrs}$ before being weighed and analysed for $\mathrm{N}$ content. For weevil inoculated plants, roots severed by the larvae were discarded so that only the attached functioning roots were processed.

\section{Results}

\section{Field trials}

At the dairy site, the top 10 clovers in terms of average vigour over three years were all white clovers. This elite group consisted of two commercial cultivars (Kopu II, Tribute) and eight breeding lines (Table 2). Vigour score for the two cultivars and the eight breeding lines were clearly superior to the average score for the remaining cultivars and breeding lines.

At the sheep/beef site, no commercial white or red clover cultivars made the top ten grouping. Prestige white clover, ranked 12th, was the best of the clover cultivars. The top ten clovers comprised four red clover breeding lines and six white clover breeding lines (Table 2). All of the red clover breeding lines in the top ten group were cree ping or spreading types. Two of these had shown superior performance under CRW pressure 
Table 3 The effect of presence (+) or absence (-) of CRW root herbivory on growth, tissue $\mathrm{N}$ concentration, and $\mathrm{N}$ content of cultivars and breeding lines of white clover. Least significant differences are for weevil treatment effects within clover lines and plant parameters.

\begin{tabular}{|c|c|c|c|c|c|c|}
\hline & \multicolumn{2}{|c|}{ —Plant DM (g) — } & \multicolumn{2}{|c|}{ - $\% \mathrm{~N}$} & \multicolumn{2}{|c|}{ —Plant N (mg) } \\
\hline & + & - & + & - & + & - \\
\hline Aran & 1.74 & 2.21 & 3.34 & 3.90 & 57.2 & 84.7 \\
\hline Apex & 1.56 & 2.02 & 3.1 & 3.97 & 46.6 & 77.8 \\
\hline Triffid & 1.49 & 2.17 & 3.67 & 4.10 & 54.6 & 87.7 \\
\hline Quest & 1.03 & 1.59 & 3.47 & 4.04 & 35.7 & 64.6 \\
\hline Kopu II & 1.68 & 2.28 & 3.66 & 4.16 & 61.6 & 94.0 \\
\hline Pitau & 1.53 & 2.12 & 3.79 & 3.99 & 58.1 & 83.8 \\
\hline Regal & 1.62 & 2.12 & 3.53 & 4.04 & 56.4 & 85.6 \\
\hline SFU × Kopu II & 1.82 & 2.39 & 3.58 & 3.97 & 63.5 & 93.0 \\
\hline Southern Europe VIII & 1.02 & 1.13 & 3.23 & 3.94 & 35.6 & 44.9 \\
\hline Syrian & 1.57 & 2.33 & 3.68 & 4.15 & 57.1 & 95.9 \\
\hline Tahora & 1.31 & 1.67 & 3.72 & 4.22 & 48.6 & 70.3 \\
\hline Tillman II & 1.45 & 1.82 & 3.59 & 4.09 & 52.0 & 74.9 \\
\hline $\mathrm{LSD}_{0.05}$ & \multicolumn{2}{|c|}{0.55} & \multicolumn{2}{|c|}{0.58} & \multicolumn{2}{|c|}{21.5} \\
\hline
\end{tabular}

in an earlier trial on a Warkworth dairy farm (Cooperet al. 2003). Only one white clover - a breeding line selected for resistance to plant feeding nematodes, made the top ten lists at both sites.

\section{Controlled experiment}

In the glasshouse experiment, plants inoculated with root weevil eggs had on average 12 larvae around their roots. Over all clover lines, larval feeding caused a highly significant $(\mathrm{P}<0.001)$ reduction in plant weight that averaged $26 \%$. For individual clovers, larval feeding had no statistically significant effect on Aran, Apex, Regal, Southern Europe VIII, Tahora or Tillman II (Table 3). The breeding line SFU $\times$ Kopu II produced the heaviest plants both with, and without the weevil. Quest (35\% reduction) and Southern Europe VIII (10\% reduction) had respectively the greatest and least percentage losses due to larval feeding. These were the two lightest clovers in the control treatment, so plant size did not determine the severity of the weevil impact on growth.

Plants with larvae had lower overall $\mathrm{N}$ concentrations $(3.57 \%$ vs. $4.05 \%)$ than weevil-free control plants (Table 3), and this difference was statistically significant $(\mathrm{P}<0.001)$. For individual clover lines, the reduction in plant tissue $\mathrm{N}$ concentration was significant $(\mathrm{P}<0.05)$ only for Apex and Southern Europe VIII.

Because these plants were entirely dependant on $\mathrm{N}$ fixation, total $\mathrm{N}$ fixed is the product of plant mass $\times \%$ N. Net plant $N$ was on average $34 \%$ lower for the plus weevil plants (difference significant $\mathrm{P}<0.001$ ). The effect on individual clovers was significant $(\mathrm{P}<0.05)$ for all clovers except Southern Europe VIII (Table 3). This calculation overestimates the impact of the weevil larvae on $\mathrm{N}$ fixation input, because no allowance can be made for plant mass and $\mathrm{N}$ lost when roots were severed by the larvae. It does estimate the size of the fixed $\mathrm{N}$ pool in live plants.

\section{Discussion}

The field trial results confirmed that modern white clover cultivars and some breeding lines have superior adaptation to current intensive dairy management over older cultivars. Agronomic fitness allows these cultivars to cope better with the additional stress imposed by CRW. Our advice to dairy farmers in CRW-infested regions is that they should sow newer white clover cultivars that are well adapted to their farming system and manage these for optimum c lover vigour. The same principles apply for sheep/beef farmers, but the choice of cultivars was less clear. Prestige clover ranked 12th from 62 on the sheep/beef farm. This medium-small leaved cultivar has high stolon density and is regarded as suitable for set stocked pastures. This confirms that agronomic adaptation is a key factor when choosing cultivars for sheep/beef pastures where the weevil is present.

The performance of a white clover breeding line selected for tolerance of plant feeding nematodes that had the highest vigour ranking for both farming systems is interesting. Clovers in northern pastures suffer from a complex range of pests e.g. nematodes (Watson et al. 1985), and clover flea, and these were present at both field sites. Our current strategy for improving tolerance of white clover to root weevil, is to achieve broader pest tolerance. This would mean the plants were under less overall stress and better able to cope with CRW. Prestige white clover is tolerant of clover flea and stem nematodes, and its performance on the sheep/beef farm supports this holistic approach to breeding for performance under pest pressures. 
Red clovers are not a preferred diet for root weevil although given no choice they will feed on them (Gerard \& Crush 2003). Red clover is a potential alternative, or supplement to white clover in CRW regions (Cooper et al. 2003), and it should be considered for inclusion in seeds mixtures. The superior performance of creeping/ spreading lines of red clover on the sheep/beef farm confirms the potential of these new red clover types, previously seen under dairying at Warkworth (Cooperet al. 2003). Red clovers showed no advantage in the Waerenga dairy pastures, but this site seems to suit white clover particularly well. The isoflavone formononetin has been implicated in the root weevil tolerance of red clovers (Gerard unpublished data). On the sheep/beef farm, a high formononetin selection of red clover ranked 60 th out of the 62 clover lines. This large-leafed erect clover obviously could not cope with the grazing regime. The result emphasises again the importance of general agronomic adaptation of germplasm before specific plant traits can be beneficially expressed.

In the controlled experiment, there was some differential response of the clover lines to larval feeding. The white clover breeding line SFU $\times$ Kopu II which produced the heaviest plants in both the + and - weevil treatments was a top performing line in the field evaluation of clover performance under root weevil stress reported by Eerens et al. (2001) (Eerens pers. comm.). Kopu II performed very well in the field trial but did not stand out in the glasshouse testing. This suggests that the low-stress conditions in the glasshouse allowed other clover lines to express growth potential which they were not well enough adapted to demonstrate in the field. All the clovers were inoculated with the same weight of weevil eggs, and it might have been expected that the less vigorous clover lines would suffer more damage than faster growing types. This was not the case because the two smallest clovers (Quest and Southern Europe VIII) had proportionately the greatest and least loss of plant mass respectively. Plants in the plus weevil treatments were paler green and appeared to be $\mathrm{N}$ deficient compared with the control plants. Nitrogen deficiency was confirmed by plant analysis, and is evidence of larval damage to nodules. $\mathrm{N}$ is also lost from the plant when roots are severed. Most plants in the weevil treatments had nodules at the end of the experiment, but they were often deep in the pots, below the level where they would normally form. This second crop of nodules provides a mechanism for clover to recover from weevil damage to nodules. The average reduction in clover $\mathrm{N}$ concentration due to weevil feeding was $12.5 \%$ which was half the average reduction in plant weight $(23.4 \%)$ so the re-nodulation mechanism is relatively efficient. However the process imposes an additional carbon sink on the plant, and diverts energy away from shoot growth. There is also the risk of further $\mathrm{N}$ losses if the roots above the re-nodulation zone are severed by more mature larvae which feed on roots. The experimental technique did not measure total $\mathrm{N}$ fixation in the weevil treatments because $\mathrm{N}$ in severed roots and nodules was not accounted for. However the results do show that the weevil larvae can have a profound deleterious effect on the $\mathrm{N}$ economy of white clover.

In conclusion, ecological theory predicts that contemporary, high $\mathrm{N}$, heavily stocked pastures will have lower clover contents than older systems that are less intensive. Clover root weevil imposes an additional stress on clover in these intensive systems. Managing pastures for maximum clover vigour will ameliorate some of the stress factors. Key factors are adequate fertilisers, avoiding pugging damage, leaving higher residual DM in summer to avoid sun damage to stolons, and utilising N-boosted grass before the clovers get shaded out. Sowing clover cultivars that are well adapted to compete better in intensive systems will optimise clover contents, but they will still be lower than in less intensive systems.

\section{ACKNOWLEDGEMENTS}

The Cotman and Hansen families for providing the field trial sites; Shirley Nichols, Li Ouyang, Tina Eden and Deb Hackell for technical support; funding from Dairy Insight, Meat \& Wool Innovation, and FRST.

\section{REFERENCES}

Cooper, B. M.; Crush, J. R.; Woodfield, D. R.; Willoughby, B. E.; Panckhurst, K. A. 2003. Red clover - a legume showing tolerance to clover root weevil. Proceedings of the New Zealand Grassland Association 65: 153-156.

Crush, J. R.; Cooper, B. M.; Woodfield, D. R.; Eerens, P. J. P.; Gerard, P. J.; Watson, R. N.; Davis, L. T. 2004. Selection of pasture legumes for tolerance of clover root weevil. Proceedings of the Australasian Conference on Grassland Invertebrate Ecology 8: 58-64.

Eerens, J. P. J.; Cooper, B. M.; Willoughby, B. E.; Woodfield, D. R. 2001. Searching for clover root weevil (Sitona lepidus) resistance/tolerance - A progress report. Proceedings of the New Zealand Grassland Association 63: 177-181.

Eerens, J. P. J.; Hardwick, S. 2003. Factors affecting clover root weevil (Sitona lepidus) numbers and clover production. New Zealand Journal of Agricultural Research 46: 305-310.

Gerard, P. J.; Crush, J. R. 2003. Feeding habituation to red clover by clover root weevil adults. New Zealand Plant Protection 56: 129-132.

Hardwick, S. 2004. Colonisation of renovated pastures 
in Waika to by four coleopteran species. New Zealand Plant Protection 57: 304-309.

Sears, P. D. 1962. Exploitation of high production pastures in New Zealand. Proceedings of the New Zealand Ecological Society 9: 57-63.

Steele, K. W. 1982. Nitrogen fixation for pastoral agriculture - biological or industrial? New Zealand
Agricultural Science 16: 118-121.

Watson, R. N.; Yeates, G. W.; Littler, R. A.; Steele, K. W. 1985. Response in nitrogen fixation and herbage production following pesticide applications on temperate pastures. Proceedings of the Australasian Conference on Grassland Invertebrate Ecology 5: 103-113. 